\title{
LAND DISPOSSESSION AS “ORIGINAL SIN". CAN CHRISTIAN ORIGINAL SIN TALK BE USED AS DIAGNOSTIC TOOL WITHIN THE PUBLIC DOMAIN?
}

\author{
Nico Vorster \\ Faculty of Theology \\ North-West University
}

\section{Abstract}

This contribution considers the descriptive value of original sin talk within the public domain against the background of the South African land reform debate. The first section analyses the employment of "original sin" language within this debate by South African President Cyril Ramaphosa in the light of the rise of "white privilege" discourse in South Africa. The subsequent section addresses the theological content and logical consistency of Augustine's version of original sin. It pays particular attention to Paul Ricoeur's analysis of the historical development of Augustine's thought on sin in response to Manicheanism and Pelagianism and concludes by identifying possible risks involved in transposing the Augustinian version of original sin talk to the public domain. The third section probes the question: Does Christian sin talk belong in the public domain at all? It examines the disconnections that exist between Christian sin talk and popular public notions of "wrongdoing". The article then considers the possible strengths of a non-literalist, non-biological version of original sin doctrine when applied to the public domain, while the last section illustrates the diagnostic benefits of the proposed version of original sin with reference to the South African land debate.

Keywords: original sin; Augustine; Ricoeur; public discourse; land dispossession; South Africa; colonialism

\section{Introduction}

"Original sin" language is used surprisingly often in non-theological literature and public social discourses. In property law original sin theory refers to the origin of property rights. It states that the manner in which governments transfer property rights to individuals has ramifications for the legitimacy of those property rights. Property rights that are transferred by means of major transgressions of law are tainted and "retain their illegitimacy". ${ }^{1}$ Within economic theory original sin refers to the inability of emergent economies to borrow capital in local currency, either in international or domestic markets, as a result of their debt composition. ${ }^{2}$ Original sin language also features in political theory studies that trace the historical "pathways" of discriminatory legislation and evaluate their enduring effect on the current status of individual citizens ${ }^{3}$ as well as genocidal studies concerned with the aftermaths of mass killings ${ }^{4}$ and post-colonial discourses about the continuing legacy of colonialism and racism. ${ }^{5}$ While these usages of original sin language are devoid of explicit religious content or references to God, they mimic the underlying components of Christian original sin doctrine: i) the notion of an original, unlawful or irresponsible act that sets in motion a tragic chain of events, ii) 
the propensity of the original act to have a lasting, enduring and systemic impact on future generations, iii) the understanding that the "original act" taints the legacy of those who benefitted historically from the particular act, and iv) the acknowledgement that such an act incurs a level of moral culpability and requires some kind of remedy.

The South African President, Cyril Ramaphosa, recently employed original sin language within the fierce and emotionally charged land reform debate in South Africa. On several occasions he described $20^{\text {th }}$ century colonial land dispossessions from indigenous people as the "original sin" that plagues South Africa. On 18 February 2018 Ramaphosa stated before the South African Parliament: "The taking of land from the indigenous people of this country was the 'original sin'. It caused divisions, hurt and pain amongst our people." He continued to argue that rectifying the situation is a "collective task" and that a variety of mechanisms are available to resolve the issue of land. This includes, among others, the possibility of land expropriation without compensation under certain conditions. ${ }^{6}$

This essay forms part of a larger project named "Redeeming sin". The project was hosted by the Department of Religion and Theology at the University of the Western Cape and included a number of annual international colloquiums. The project examined a challenging and daunting question: Is it possible to retrieve Christian sin-talk in the public sphere $?^{7}$ My essay contributes to the project theme by exploring the topic of original $\sin .^{8}$ I specifically ask whether we can transpose the theological concept of original sin to the public realm in a constructive and useful manner? Various subquestions follow: Would the public use of a theological term not compromise the integrity of Christian doctrine? What are the social risks involved in applying the concept to the public realm? Are there any moral benefits to using the concept as a diagnostic tool within the public domain? I probe these interrelated questions against the concrete background of the South African land debate, specifically President Ramaphosa's use of original sin language as a moral entry point to the conversation on land reform.

\section{Original sin language in the South African land reform debate}

Ramaphosa's use of a theological concept within the extra-religious domain of politics received mixed reactions. Some land activists embraced it, while others openly denounced it. The South African Institute for Race Relations, for instance, publicly repudiated the remarks by stating that "doctrines of collective guilt have no place in a democracy founded on individual rights". ${ }^{9}$ We therefore need to ask: Why would Ramaphosa use a theological term within the political domain where juridical and constitutional language are perhaps more appropriate?

We can safely assume that political optics and rhetorical impact were important considerations in Ramaphosa's well-choreographed choice of words. South African politicians often employ pseudo-theological notions in political rallies, especially when they address church leaders and adherents of traditional African religions. But Ramaphosa's original sin remarks have a different sound to them. He employed the term in a speech before Parliament, not a religious audience. His use of the concept was also not a once-off event: he consistently and persistently utilised the term in subsequent speeches as a political-philosophical and moral entry point to the topic of land reform. ${ }^{10}$

Two other key factors also need to be taken into account when evaluating Ramaphosa's comments. Firstly, his original sin narrative emerged against the 
background of a wider postcolonial political discourse in South Africa about white privilege and intergenerational accountability. Ramaphosa on several occasions publicly endorsed the logic of the white privilege narrative. ${ }^{11}$ This argues that "whiteness" continues to act within previous colonial societies as a normative category against which other racial groups are valued, making colonialism an enduring mode of existence. ${ }^{12}$ Whites still enjoy structural advantages of power in these societies and are afforded "taken-for-granted benefits and protections" based on their skin colour. ${ }^{13}$ The "white condition" is made possible by structures and processes that allow benefits to continue flowing to white people. To rectify this state of affairs, societies need to incorporate notions of "backward liability" in their legal discourses, and they should accept that Person A can be held accountable for the sins of Person B when they have benefitted indirectly from the actions of Person B. The South African white privilege narrative claims that since colonialism and Apartheid legislation appropriated land from black people unjustly, the profits from land that current white owners enjoy, can be considered unjust. The State can therefore not be expected to use market mechanisms to determine current values of land, nor can it be expected to compensate owners for land obtained illegally. ${ }^{14}$ The Vumelana Advisory Fund articulated this viewpoint as follows before the Parliamentary land hearings held in September 2018:

There is a sense of continuing injustice in the idea that those who profited from the land from which the original land occupants were removed without compensation should keep their profits and be compensated for the land they are now required to give up. ${ }^{15}$

Secondly, Ramaphosa used the term “original sin" within a specific political context. He attempted to silence political opposition to his land reform programme by providing a moral justification for the ANC policy of expropriation without compensation under certain conditions. On the one hand, Ramaphosa had to counter liberal arguments that individuals cannot be held accountable for the sins of past generations. Original sin tells us that racial and social inequality in South Africa can be related to a specific point in time in South Africa's history - a primal sin - namely the implementation of the 1913 Native Land Act and the 1936 Native Trust and Land Act that dispossessed many black South Africans. Ownership patterns had a sense of normality before the legislation was introduced, but the "sinful act" of this legislation produced the current state of unequal land distribution. The "original sinners" are historically liable for what went wrong. Backward liability and redress are warranted, not only when it comes to the original sinners themselves, but also those who benefitted from the original sin. Ramaphosa also employed original sin to refute the fatalist argument of neo-classicist economists and agriculturalists who claim that wrongs of the past cannot be rectified without endangering future prosperity. Original sin signifies landlessness as an "ongoing" disease that cannot be left untreated. It holds that the negative after-effects of land dispossession are trans-generational, systemic and enduring in nature, and that the "disease" of skewed ownership patterns will not be cured without a collective social response. 
At face value, the original sin doctrine provided Ramaphosa with a powerful conceptual tool to promote his political agenda of land restitution and restorative justice. However, transposing the theological concept of original sin to the political domain without a substantive theological context can have unintended consequences.

\section{The "risks" of transposing original sin talk to the public domain}

In an essay entitled: Original sin. A study in meaning, first published in 1960 and republished in The conflict of interpretations (1989), Paul Ricoeur warns that we cannot speak about original sin as if it is a concept with proper rational consistency. ${ }^{16} \mathrm{He}$ bases his argument on historical analysis of the theological and philosophical cross-pressures that Augustine faced when he formulated his doctrine on original sin. ${ }^{17}$ Ricoeur suggests that Augustine developed the notion of peccatum originale as a response to Gnosticism on the one hand and Pelagianism on the other. The unfortunate result was that an "antiGnostic" concept became a "quasi-Gnostic" doctrine based on a literal interpretation of the creation narratives and an erroneous exposition of Romans 5:12 and 19.18

Ricoeur emphasises that the term "original sin" is not directly derived from Scripture. The Biblical traditions largely use the metaphor of "captivity" when speaking about the effects of sin on human nature. Unfortunately, Augustine and certain strands of Reformed theology transformed this biblical image into a speculative and abstract rational concept that operates with juridical debt and biological inheritance categories. ${ }^{19}$

Gnosticism locates evil outside the agency of the human being in matter itself, thus awarding evil ontological status. It views sin as the result of the soul having been infected by the evil of matter, the body and the world. According to Ricoeur, the Church Fathers responded to the Gnostics by asserting the non-being of evil. Evil is not substance, nature or matter, but consists of "doing". Appealing to the creation narratives, they claimed that sin entered the world through the acts of the first human being, which means that "sin is not the world, but comes into the world". ${ }^{20}$

Sharing the Church Fathers' line of thought, Augustine, in his refutations of Manicheanism (a particular form of Gnosticism), reverts to an ethical understanding of evil. Sin is a deficient movement of the human will away from God; it finds its origins in non-being. ${ }^{21}$ According to Ricoeur, the question Augustine faced, was: How can the ethical understanding of sin be reconciled with passages such as Romans 9:10-29 that speak of the election of Jacob and the rejection of Esau before their births? Moreover, Augustine had to contend with the Pelagian movement, which portrays sin as a voluntary individual act based on imitation rather than necessity. The Pelagians also contested the possibility of one person being punished for the sins of others. ${ }^{22}$ This position naturally had drastic implications for orthodox Christology and the Pauline doctrine of grace.

To avoid Pelagian voluntarism and explain the human condition of sin, Augustine introduced the notion of inheritance. He contends that Adam was the initiator and propagator of sin when, as the primal ancestor, he transmitted the disease of sin to all of his descendants. ${ }^{23} \mathrm{We}$ are all infected by sin, and thus we are accountable to God. According to Ricoeur, Augustine based this view on his erroneous interpretation of Romans 5, where Paul sets Adam as anti-type against Jesus, who represents the ideal

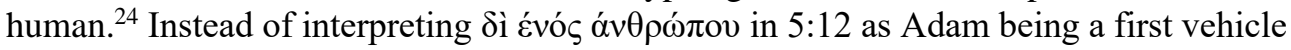
of $\sin$ in a "supra individual" sense, Augustine understood the term to denote Adam as the first agent of $\sin .{ }^{25}$ The result was the loss of the mythic dimension of the Adamitic 
figure - which was still present in Paul's reflection - and the emergence of a juridical notion of "individual guilt corrected by a biologism of hereditary transmission". ${ }^{26}$

Ricoeur concludes his genealogical discussion of the development of Augustine's concept of original sin with a sharp rebuke:

It will never be said enough just what evil has been done to Christianity by the literal interpretation, the "historicist" interpretation of the Adamatic myth. This interpretation has plunged Christianity into the profession of an absurd history and into pseudo-rational speculations on the quasi-biological transmission of a quasijuridical guilt for the fault of an other man, back into the night of time somewhere between Pithecanthropus and Neanderthal man. ${ }^{27}$

Ricoeur's otherwise informative examination contains one fundamental weakness: it does not take the central motive in Augustine's thought adequately into account. In Augustine's thought the comprehensive nature of sin serves as a foil to God's radical and encompassing grace. We are all sinful and guilty before God and are thus salvaged by God's grace alone. That said, Ricoeur's critique unveils shaky theological elements in Augustine's doctrine of original sin: it makes the error of interpreting archetypal, symbolical and metaphorical literature as literal history, it provides an erroneous exposition of Romans 5:12 and it abandons a metaphorical approach to sin as found in creation narratives, only to replace these with an exhaustive but self-contradicting, rationalist explanation of the transmission of sin.

Ricoeur's critique of Augustine's literalist notion of inherited sin is echoed by prominent $20^{\text {th }}$ century theologians, most notably Karl Barth and Reinhold Niebuhr. Barth calls for the total abandonment of the concept of inherited $\sin ,{ }^{28}$ while Niebuhr, in a similar vein, appeals for the cleansing of the original sin doctrine from "literalistic illusions". Niebuhr claims that the notion of "an inherited second nature" actually contradicts the idea of human responsibility for $\sin .^{29}$

So, can we transpose a concept that lacks consistency to the public domain, despite its weaknesses? With this question, various challenges come into focus. A first major obstacle is the historical plausibility of Augustine's doctrine. He understood the fall as a literal historical event committed by an original pair of human beings that altered the moral and biological dispositions of human nature. However, when we construe the creation narratives simplistically as literal science or history, we lose, as Duffy contends, "their genuine insights". ${ }^{30}$ The creation narratives contain prose, poetry, metaphors and symbols that introduce us, in the words of Karl Barth, to a world of "prophetic witness", "intuition" and "imagination" where "events are no longer susceptible as such of historical proof". ${ }^{31}$ The absurdity of literalist interpretations of the creation narratives become even clearer when we compare them with paleontological and biological information on the natural history of humankind. McFarland summarises this as follows:

It is now beyond dispute that there was no point where human existence was characterized by immunity from death, absence of labor pains, or an ability to acquire food without toil. Nor are the facts of evolutionary biology consistent with 
the descent of all human beings from a single ancestral pairing and nothing suggests that humanity's advent occasioned any change in the basic conditions of biological existence. $^{32}$

The literalist error and historical implausibility of Augustine's doctrine on the origin of sin not only pose a complex set of theological problems, but are also problematic from a public point of view, because the public sphere has to operate with diagnostic tools that are plausible and conform to basic standards of rationality. In a debate as sensitive as land reform, we need to apply moral language with a demonstrable factual basis.

Another major obstacle is the outdated anthropology that underlies the doctrine. Jenson describes the classic notion of human nature as highly problematic, because it understands human nature as something "given to each of us by our biological generation which hands on a deprived and infected version of that nature". ${ }^{33}$ But the notion that the first pair transmitted the alteration of human nature is theologically not a "sufficient explanation". It suggests an "impersonal something" that makes us human, the alteration of which can bring about a change in the "definition of humanity". ${ }^{34}$

Augustine regarded the soul as the controller of the body. After the soul deserted God through a wilful act of disobedience, it lost its ability to control the lower passions of the body. Sexual concupiscence and lust now exercised hegemony over the rational dictates of the human will. Human beings were conceived in sexual desire and, by means of this illicit desire, sin was propagated to subsequent generations. ${ }^{35}$ The natural state of the human being and the unity between body and soul were ruined as a result of sin, because God submitted the human body to death and destruction. ${ }^{36}$

The difficulty in transposing this aspect of Augustine's doctrine of original sin to a modern context should be clear: The idea that sin (a moral notion) can be transmitted to human generations through sexual intercourse (a biological act) is, anthropologically speaking, not intelligible. Herman Bavinck rightly observes that sin can never be conceived as a substance that settles in the human body that can be transmitted through procreation. This would imply that bodily human nature is, somehow, evil. ${ }^{37}$

Thirdly, Augustine's fusion of biological and juridical categories risks obliterating the important link between human accountability and human agency. Maintaining the link between human accountability and human agency is vitally important within criminal justice discourse, since the alternative would be to enter the realm of arbitrary justice. Once we ascribe guilt and culpability to a person in the legal realm based on their lineage or group association without taking into account the person's own agency and actions, a space is created for arbitrary discrimination. The most notorious crimes committed against humanity in the $20^{\text {th }}$ century generally had one feature in common: a group of people were considered as undesirable simply because of their lineage, religion, group belonging or supposed criminal history and the law was subsequently used to persecute or discriminate against them. These cases clearly illustrate the danger of collectivist and arbitrary notions of guilt or innocence. When it comes to land, events in Zimbabwe serve as a vivid reminder of the disastrous effects that an arbitrary application of justice can have on a country. When we respond to injustice by doing injustice we not only lose our moral compasses, but we also create spirals of wrongdoing. 


\section{The compatibility of Christian sin talk and public discourse}

If the Augustinian version of original sin is not transposable to the public domain, what about other types of Christian sin talk? McGrath rightly notes that Western culture has been deeply influenced by the Pelagian sin doctrine, even though its name means little to most people. ${ }^{38}$ Pelagianism upholds the free will of the human being and preserves the close bond between human agency and human accountability. It claims that moral actions and merit stand in a proportional relationship to each other and it dispenses with any notion of inherited guilt. It does not view sin as a permanent condition, but as a contingent moral act that emanates from the abuse of free will. At face value, it seems that public and juridical discourse can utilise this concept of sin quite easily.

But here we also encounter various difficulties. ${ }^{39}$ Pelagianism tends to understand the human will as an unconditioned neutral mechanism that can freely choose between competing options. When we cannot make decisions, we are in a position of coercion, and not engaged in a process of willing. ${ }^{40}$ Theoretically speaking, then, Pelagianism holds that it is possible for human beings not to sin, and even if they sin, they are always in a position to return to a neutral position of decision making. Semi-Pelagianism softens the voluntarism of Pelagianism somewhat by recognising that the human will is weakened by sin and that moral perfection is not possible, but it still claims that the human propensity for good combined with divine aid can overcome sin.

The biblical traditions largely use much more radical language when it comes to sin. As Horton rightly observes, sin is not something that can be overcome by simple "moral instruction" or "social engineering". ${ }^{41}$ We are, in Paul's words, slaves of sin. ${ }^{42}$ Our wills are not merely weakened by sin, but in bondage to it. The Reformers described the tragedy of human existence with the phrase "total depravity", which means that all parts of human existence are contaminated by sin; "there is no Archimedean point within us that is left unfallen." ${ }^{43}$ Hence, sin involves more than an act of wrong imitation. It denotes a condition of captivity and enslavement, a malevolent compulsion that preconditions our will and captivates us. Paul states it most eloquently in Romans 3:10-11:

As it is written:

'There is no one righteous, not even one;

11 there is no one who understands; there is no one who seeks God.

12 All have turned away, they have together become worthless; there is no one who does good, not even one.'

Pelagianism's "thin notion" of sin inevitably leads to a thin Christology and soteriology that reduces Christ to a moral teacher, and grace to external divine guidance. The biblical traditions, in contrast, tend to magnify the radical nature of sin and the encompassing nature of God's grace, de-emphasising human autonomy and resisting the possibility of the human attainment of salvation through good works. ${ }^{44}$ 
From a political point of view, we could also argue that Pelagianism is too naïve a doctrine of sin to transpose to the public domain. Its weakness lies in not taking humanity's solidarity in sin seriously enough. It glosses over the harsh and cruel aftereffects of sin by proclaiming that every human being is in control of their own destiny and that we can conquer sin through human ingenuity. But reality tells us otherwise. The land debate in South Africa serves as an apt reminder that sin entraps generations of victims in vicious cycles of poverty and landlessness. Disparate acts of land dispossession have resulted in a condition, a mode of existence, which is almost impossible to reverse without risking food security, social conflict or severe damage to the economy. South African society is in the precarious position of having to choose between different evils. Niebuhr rightly contends that the Pelagians are so focused on asserting human freedom that they do not realise that "the discovery of this freedom, also involves the discovery of man's guilt". ${ }^{45}$

If both Pelagianism and Augustinian original sin doctrine do not meet the criteria for an adequate explanation of wrongdoing, should Christian sin language be used as a diagnostic tool within the public domain at all? Theological sin-language and public discourses do not seem at face value to be a natural fit. Three considerations immediately come to mind.

Firstly, Christian sin talk has God as referent. Jenson argues that sin relates to that which God does not want us to do. Without acknowledging God as the norm of righteousness, we are unable to employ the concept properly. ${ }^{46}$ Public discourses, on the other hand, generally attempt to avoid metaphysical concepts. While the existence of God and the authenticity of religion are not necessarily rejected, in most democratic societies God-talk is relegated to the private and subjective realm of personal decision. ${ }^{47}$ After all, human rights discourse finds its origin in the liberal endeavour to forge a universal moral language based on rational premises that would allow for a minimum consensus between divergent worldviews. Christian sin talk seems to undermine the liberal project.

Secondly, Christian sin talk is generally connected to Christology. For Christians, the pervasive and total nature of sin magnifies the radical depth and wide-ranging implications of God's grace. Within the extra-religious domain of politics, law and economics this connection is lost. Christ does not occupy a central place in the cognitive framework of the average politician, social philosopher, lawyer or economist.

Thirdly, Christianity does not equate divine justice with human justice. Human justice connects deeds to merit and actions to just reward or punishment. Divine justice, as understood within most Christian traditions, is a gift that transcends moralist notions of action-reward, cause and effect. Jesus' parable of the workers in the vineyard serves as a vivid reminder of this. ${ }^{48}$ The point Jesus makes in this parable is that God is not constrained by human notions of justice. He has the right to show mercy to those who come last and deserve it the least. He is the wholly other, the Sovereign whose acts of justice are not necessarily comprehensible to the human mind or subject to human norms of justice. In fact, the Christ event defies conventional human logic about sin, guilt and justice. Vorster states as follows:

God does not follow conventional justice logic, but embraces us in a manner that circumvents human logic, undercuts human autonomy, surpasses due process and 
defies retributive logic to make a new beginning possible. The Christ-event was a once-off non-repeatable event executed by a God who Himself is the norm of justice. Finite human beings cannot execute justice in the same manner. ${ }^{49}$

Since God is Sovereign when it comes to justice, divine forms of justice cannot be applied to human contexts in an unqualified manner, nor can human justice be simplistically modelled on divine justice.

Lastly, we need to recognise that Christian concepts of freedom and guilt and modern notions of liberty and culpability differ significantly. Biblical language depicts sin and grace as conditions or states that pre-empt human willing, eventually emerging in particular acts. ${ }^{50}$ Neither the gospels nor Pauline literature refrain from describing the whole of humanity as captives of sin and as culpable before God, even before their births. ${ }^{51}$ Old Testament literature also exhibits no qualms in assigning guilt in a corporate sense to Israel, Edom, Babylon or Nineve. God's grace is viewed, almost without exception, as a gift rather than a reward.

Augustine attempted to capture this biblical way of thinking about sin and grace with the concept of original sin. For Augustine the unmerited gift character of God's grace so clearly articulated by Paul - implies that all human beings are sinners incapable of redeeming themselves. ${ }^{52}$ Human beings stand before God in a state of guilt, because even though the human will is enslaved by sinful desire, it still acts willingly of its own accord and is therefore culpable before God. ${ }^{53}$ This Christian approach to freedom stands in stark contrast to secular, liberal and legal understandings of freedom as consisting of human agents making decisions free of external compulsion, and culpability as related to recompenses based on intentional individual acts.

Using Christian concepts of sin as diagnostic tools within the public realm might seem pointless at this stage, both from a theological and public point of view. One may argue that Christian sin talk should be limited to the ecclesiastical domain, because the integrity of Christian doctrine can only be compromised when employed in public debates. But McFadyen rightly observes that such an approach risks colluding with the "general retreat of God talk in the public life". ${ }^{54}$ The Christian faith makes universal claims, analyses the human condition, considers its message as a truthful perspective on reality and proclaims the reign of Christ over the whole of human history. Another option could be to evacuate Christian sin talk from all references to God and to translate it into neutral political language to make constructive public discourse possible. But is sin talk without God as referent not, as McFayden rightly asks, a form of "pragmatic atheism", a "rhetorical flourish" with descriptive power? ${ }^{55}$ Does this approach not allow secular discourses to set the standards for public discourse and is it not in essence selfdefeating? ${ }^{56}$

In addition, the secular-liberal outlook on the make-up of the public realm should not be taken for granted. The modernist notion of a neutral, objective public realm where liberal rights discourse determines the procedural and ideological framework of public interaction is not entirely intelligible. Are secular discourses not themselves fighting creeds undergirded by worldviews, structural understandings of reality, anthropologies and vested power interests? How plausible are the dualist patterns that underlie 
liberalism's worldview? Do liberalism's binary distinctions between the objective and subjective, public and private, and sacred and profane reflect the complexity of lived experience?

We also need to ask: Why should liberal discourse be afforded the right to dictate the rules of discourse in the public sphere, especially in a highly diverse society such as South Africa? Surely social groups ought to be allowed to participate in public life without being expected to relinquish the fundamental tenets of their worldviews. They ought to be allowed an opportunity to persuade others, admittedly without imposing their views coercively on others simply by demanding consent. But how can social groups persuade others if they are not allowed to speak in their authentic language within the public domain?

My point is the following: Christians should not be prevented from participating in public debates in the language of their choice and they should not be scared of using Christian sin language in social discourses. The explanatory and descriptive power of Christian sin talk will reveal - or not reveal - itself in practical situations. When original sin talk exhibits deficiencies it should be revisited like any other doctrine. McFadyen states the need for an openness to doctrinal renewal poignantly:

... doctrinal continuity is not something we receive from the past, but something we find and recognize in the present - not merely in, but for, to meet the demands of, the practical and theoretical exigencies of particular situations.

\section{Revisiting original sin doctrine}

Thus far, I have argued that the Augustinian version of original sin shows deficiencies. But at this stage we also need to note that even the harshest critics of Augustine's notion of original sin - Schleiermacher, Ricoeur, Barth and Niebuhr - are not prepared to abandon it entirely. They leave behind the Augustinian version, but still embrace the truth of original sin. Why would this be the case? Is Christian original sin talk not perhaps resurfacing within the public domain because it provides a descriptive tool that few other moral languages can offer, especially when it comes to addressing historical injustices and the systemic impact of wrongdoing? In what follows I will argue that original sin is indeed a useful descriptive tool that can be used in the public realm, but it needs to be cleansed of doctrinal constructs that are unnecessary, implausible or not profoundly biblical.

I have already discussed the impasse that a literalist and biological notion of original sin creates. The question now is whether a non-literalist and non-biological understanding of original sin that maintains God as referent and dispenses with the classic notion of the soul as controller of the body will improve the doctrine's explanatory and descriptive power. A non-biological, non-literalist understanding of original sin presents, in my view, a more plausible descriptive tool than the Augustinian version of original sin. Two qualifying remarks are appropriate in this respect. First, we should not confuse a non-biological understanding of original sin with a rejection of the universal, corporate and habitual nature of sin, nor see it as an attempt to refute the culpability of human beings. It does, however, deny sin an ontological status. Secondly, we should not equate a non-literalist understanding of the creation narratives with a non- 
historical understanding of original sin. Non-literalism does, however, remove historically implausible narratives from sin talk.

Biological notions of sin are theologically unacceptable because they ground sin in the creaturely nature of the human and hence award sin an ontological status. Biblical thought is clear on this point: sin is not part of God's creation or his intent. Biological concepts of sin could actually serve as a recusal for human sinning, because they locate sinning in the physical make-up of the human rather than human willing. Sin is universal and radical not for the reason that it is transmitted biologically from one generation to another, but because it is an overwhelming and captivating condition that disorients the human will and preconditions human freedom. Sin shapes our lives even before we are capable of making moral judgements. ${ }^{57}$

By describing sin as a condition, we are not depicting sin as a "thing" or substance, but as defection; the absence of good; as a negating, distortive and parasitical power alien to God. It preys on God's good creation and manifests itself in individual, supraindividual and collective acts of human wrongdoing. We can explain this by referring to freedom. Freedom is a gift of God to humanity; it is a basic precondition for an authentic I-Thou relationship between God and human beings. Relations devoid of freedom can only be coercive in nature. But freedom also provides an opportunity for humans to choose and act against the will of God. In other words, the gift of freedom, which is an essential part of a good creation, is in its very nature also prone to distortion and perversion. This is where the power of sin lies: it preys parasitically on the good gifts of God's creation by distorting, perverting and re-orienting them to bad ends. We sin inevitably, not as a result of our physical make-up nor because sinning is a necessity, but because human willing is cut off from God as the Source of life. Reality cannot be adequately understood or explained without reference to God, nor can we act properly without discerning God's will for our actions. ${ }^{58}$

Sin also has a corporate historical dimension. Jenson rightly notes that there must have been a "historical first happening of what thereafter always happens", an act of disobedience by the "first community of our biological ancestors" ${ }^{59}$ Genesis 3 may not narrate literal history, but it tells of an original event that certainly occurred. Following Plantinga, Conradie rightly indicates that as soon as we accept that things are not the way they should be, we are working with at least a minimalist notion of the fall. ${ }^{60}$ However, the use of original sin and fall language should not be misconstrued as an attempt to explain evil's origin. ${ }^{61}$ Original sin rather refers to the pervasiveness of sin; it teaches that human history is diachronically related, that we do not merely sin alone, but also through and with others, and that our acts are socio-politically and "historically connected". 62 Thus human history has seen the formation of continuous chains of sin and cycles of evil and their replication time and again. Freedom in its pure authentic form no longer exists; we are alienated from God who is the Source of good, we are bound by the structural consequences of previous abuses of freedom, we live in a world devoid of innocence. Yet, as Bonhoeffer rightly points out, we should not recuse ourselves by making the chain of events itself responsible for our deeds. ${ }^{63} \mathrm{We}$ are ourselves compulsively drawn to abusing God's gift of freedom and we often participate in the sins of past generations either actively, by consent or through deadly silence. The human 
propensity to self-recusal is sadly illustrated in the denialism and indifference that many landowners in South Africa exhibit with regard to past land dispossessions.

The human will cannot resist the captivating power of sin and the temptation to use God's gift of freedom for bad ends. Sin finds its basis in human actions, but it is more than simply "doing", it is depravity, since we cannot return to a "neutral" position of innocence. Human wills are no longer free, but in bondage. To illustrate the descriptive power of a non-literalist, non-biological understanding of original sin we return to the South African land debate.

\section{Original sin talk and the South African land debate}

South Africa's tragic land history affirms the basic truths contained in the original sin doctrine: the pre-conditioned nature of human willing; the radical and systemic nature of sin; sin as opposition to God; and our corporate solidarity in sinning.

The South African Native Land Act of 1913 and the Native Trust and Land Act of 1936 relocated black South Africans living in rural areas to so-called native reserves or traditional areas. Rural blacks were arbitrarily and forcefully removed from the land they inhabited, received no monetary compensation and were prevented from buying or selling land outside the reserves. Within the newly established reserves they were only allowed conditional usage rights of land under trusteeship of the State. The native reserves were small and overcrowded, infrastructure was poorly developed, and the land allocated was largely unproductive. ${ }^{64}$

The land grabs did not meet much resistance from either the white community in South Africa or the British colonial authorities who ruled South Africa at the time. The lack of resistance highlights the conditioned nature of "white" thinking at the time. By the first part of the $19^{\text {th }}$ century white mindsets and white values were already framed for at least two centuries by colonialism and a patriarchal ideology that idolised "civilisation", progress, hierarchy, victory, white and Christian exceptionalism, patriotism and heroism. The Cape was colonised by the Dutch in 1652, and then by the British in 1795. Afrikaners (offspring of Dutch settlers) penetrated the South African interior from the 1830's and colonised black land which they regarded as terra nullus, while British rulers introduced black native reserves on Natal's eastern coast as early as the 1840's. The promulgation of the 1913 and 1936 land acts was the culmination of thought patterns and habits that had been established long since, and thus presented no moral affront to most whites.

Patriarchy shaped white identity formation, and acted as the basic premise for choosing and willing various outcomes. It became the force behind the fibre of society, the dynamics behind white decision making, the invisible hand that arranged the very structure of colonial society. To be sure, colonial identity and patriarchy did not force the hand of white South Africans as if they had no alternative but to follow these land policies, but it captured their inner intentionality and moral judgement. Inequality and hierarchy were seen by many as part of the divinely intended order of things, while freedom and equality were considered as humanist values that disturbed God's natural order. Land grabs were accepted as legitimate interventions for the sake of the common good; as the right thing to do in order to nurture civilisation in South Africa and build a strong economy. Patriarchy indeed captured white "willing" to such a degree that the white collective actually became incapable of unambiguously discerning good. 
The 1913 and 1936 land grabs as well as a whole range of subsequent laws that governed black ownership created a highly unequal land structure consisting of an underdeveloped black peasant farming community and a technologically advanced white commercial farming sector. ${ }^{65}$ Many black men were forced to leave the reserves and their families to seek work at mines and urban sectors where they supplied cheap labour. The end result was a chain reaction of "gradual" black impoverishment and the near destruction of rural black family life. ${ }^{66}$ Land dispossession, segregation laws (19101948) and the system of Apartheid (1948-1990) created trajectories where the racial characteristics of a person and the group to which they belonged determined their opportunities in terms of access to land, property, jobs, education, voting rights and economic advancement. These dynamics simultaneously gave rise to cycles of violence and counter-violence.

These events illustrate the systemic impact of sin on generations of people. In the South African case, sinful racial discourse penetrated white identity formation, permeated collective white consciousness, entered social policymaking processes and eventually culminated in oppressive social structures that reigned over every inch of society. To maintain these social structures and to curb resistance, the State applied violence, while liberation movements responded with violence. Ordinary people were caught in between. Simple options between right and wrong no longer existed; innocence was lost. Sin indeed became a destructive systemic power; it was no longer a loose collection of individual acts, but a condition into which people were born and had to frame their existence.

South Africa's land history offers a clear illustration of collective opposition to God. Systematic land dispossessions almost always coincide with group egotism, greed, violence and injustice. As such they all constitute acts against God. Yet, some transgressions are directly aimed at God and directly refer to God. Blasphemy is one such example and, in the case of South African land dispossessions, idolatry and despair immediately come to mind. Jenson defines idolatry as follows:

Idolatry is our persistent and ingenious and even noble attempt to use deity for our own ends; in this attempt we necessarily posit a middle realm in which to meet and negotiate with deity, and "idols" are whatever then emerges to conduct the negotiation. ${ }^{67}$

A wide variety of religious ideologies were used to justify land grabs in South Africa. Nineteenth century British colonialism considered land invasions as a "missionary endeavour" that would bring the gospel to "pagan nations", while the Afrikaner Voortrekkers used a literalist understanding of Old Testament promised land and conquest narratives to identify themselves as the elected "Israel", with the duty to drive away heathen nations from God's promised land. ${ }^{68}$ In bestowing on themselves the status of the "enlightened" or "elect", the British and Voortrekkers engaged in a form of selfdeification, a collective pride, that made the interests of the group the norm and ultimate end. 
Twentieth century Apartheid ideologies became more sophisticated. South African Calvinists distorted Dutch Neo-Calvinist teachings on sphere sovereignty to claim that every nation was created to be autonomous and sovereign. In practice this would entail that different racial groups should live apart. Theologians from the Dutch Reformed Church in South Africa, moreover, utilised neo-Fichtean philosophical notions to argue that God created every nation with an "own soul" or temperament. This view held that, depending on their exposure to the gospels, nations exhibit differing levels of cultural sophistication. There exists a kind of hierarchy, a higher and lower order of nations. The cultures of higher order nations should not be contaminated with the values of lower order nations. ${ }^{69}$

If religious language was the facade used to justify land dispossession, anxiety can be considered as the innermost motive, and selfish acts of despair as the outcomes. Anxiety, as Kierkegaard so eloquently indicates, is not the actuality of sin but "the psychological condition that precedes $\sin "{ }^{70}$ Anxiety creates insecurity, which leads to despairing acts of self-preservation at the expense of others. By allowing anxiety to control our decisions, by attempting to take control and establish our own independence, we emancipate ourselves from God and overreach the limits of our creaturely nature. Hence anxiety creates a breeding ground for direct opposition to God. ${ }^{71}$ Fear of the "black danger" was a central motif in $20^{\text {th }}$ century white politics and indeed a rallying cry during elections. As was the case with the implementation of segregation and Apartheid policies, South African land dispossessions were designed to secure the interests of the white minority in a country where blacks constituted the vast majority of citizens. By controlling the natural resources of the country, and by hindering black economic advancement, the white minority hoped to maintain a grip on power. Their acts not only constituted an attempt to emancipate themselves from God, but also revealed a nihilistic sense of despair.

This brings us to the most unsettling component of original sin discourse, namely our universal guilt and culpability. Can young white South Africans who were born into a situation of $\sin$ be exonerated from culpability or guilt on the basis that they themselves did not commit any crimes? Liberal discourse would probably say "yes", based on the principle that moral accountability cannot be severed from moral agency. We can agree to some extent: young white South Africans born in the post-Apartheid era can certainly not be held criminally or legally accountable for the sins of past generations. Criminal justice is, after all, concerned with specific intentional acts of legal transgression. As noted earlier, when we persecute people on the basis of others' transgressions, we enter the realm of arbitrary justice. But we also need to distinguish between legal culpability and moral culpability. Illegality and immorality are not always the same thing. In line with original sin discourse, we could indeed argue that young white people cannot exonerate themselves from moral guilt and culpability, because they have benefitted and are still benefitting from the chain of enrichment and privilege that Apartheid brought to white people at the expense of black people. Once you share in the benefits of wrongdoing, you are contaminated, and cannot extricate yourself from the situation, even though you did not intend to cause anyone any harm. Young white South Africans may not be legally accountable, but they do carry a moral burden that needs to be acknowledged, and they have a duty to confront the evils of the past. 
Those who fell victim to Apartheid laws should, however, not lose sight of the bigger picture nor be in a hurry to claim righteousness. Many gruesome acts were committed in the name of the "struggle" and considerable innocent blood was spilled in the name of freedom. The tragedy of human existence is that all of us benefit in some way or another from the sins of past generations, whether it be the violence that my fathers committed in wars to bring me freedom, or anything else. Volf correctly observes that the very act of dividing parties "into pure and corrupt entails corruption". ${ }^{72}$ Every person carries a moral burden; no-one is righteous, because we are all compromised by events that extend beyond our own moral agency. The make-up of our sins may differ in severity and range, but we are all involved and morally culpable in some way or another. This is the tragedy of human existence that the original sin doctrine articulates so clearly when it speaks about the universality of sin, the intergenerational communication of sin and our guilt before God. Yet, as Volf rightly notes, the universality of sinning should not be confused with equality in sinning. ${ }^{73} \mathrm{We}$ are all victims and perpetrators in some way or another; but not equally so. To deny this reality would be to "disguise the suffering of victims and to obfuscate human evil". ${ }^{74}$ Those in power, who have the resources to influence events, carry a higher moral responsibility for their actions than those who respond to what life throws at them.

Seen in the light of South Africa's land history, Ramaphosa's choice of words was perhaps not as ill-advised as some may assume. When it comes to substance, the diagnostic tool of "original sin" allowed him to articulate the complexities and aftereffects of land dispossession at a deeper and much more profound level than terminologies restricted to human rights, constitutional or legal language. Postcolonial, Marxist and feminist thought have rightly exposed the limits of liberal rights discourse when it comes to issues of redress. They indicate that human choices are always made within the limits of social and institutional contexts and that past forms of discrimination have a profound impact on the outcomes available to a person. Fundamental rights discourse seems to fall short in this regard. It finds it difficult to accommodate notions of "redress" in its vocabulary, because it is concerned with individual rights and specific evidence-based abuses, whereas "redress" is concerned with the systemic after-effects of crimes committed against particular groups. ${ }^{75}$

Should Christians hence congratulate Ramaphosa on reintroducing a Christian concept to the political domain? I don't think so. The South African President's intuition about the truth of "original sin" doctrine may have been correct, but his application of the concept is highly problematic. Ramaphosa erred in evacuating a Christian concept from any reference to God; and by applying a religious-ethical term to the legal domain. Removing God from the picture inevitably emanates in the universal nature of sinning being denied and guilt and culpability being narrowed down to interhuman relations. It is no longer we as a collective who sin against God and our neighbours and have a shared moral burden to carry together; but rather a case of they who sin against us and owe us redress. Moreover, by applying original sin doctrine to the realm of property rights, Ramaphosa gave significant impetus to the arbitrary concept of expropriation without compensation being introduced to South African law. As noted earlier, "original sin" is not a juridical concept but a theological-ethical concept that depicts the moral and 
spiritual condition of humankind. When applied outside the realm of ethics and social diagnostics, it can be used as a tool of oppression.

\section{Conclusion}

The doctrine of original sin is indispensable to the Christian faith. It presents a "thick" understanding of sin that encapsulates humanity's universal culpability with reference to God, the bondage of human willing and the universal, corporate and systemic nature of sinning. It is also much better aligned to the Christian doctrine of salvation by grace alone than either Pelagianism or semi-Pelagianism. However, for the Christian concept of original sin to be theologically plausible, it must be cleansed from biological, literalist and juridical-debt interpretations. Biologism risks ascribing sin to God and can only serve as a false recusal for our sins. Literalism tend to use original sin as a heuristic device to explain the origin of evil. Juridical-debt interpretations inevitably lead to retributive talk. I believe that a non-biological, non-literalist understanding of original sin that emphasises the universal, systemic, inevitable and pervasive nature of sin would safeguard the Christian faith against these tendencies.

From a social point of view, original sin discourse provides descriptive tools that few other moral languages offer, especially when it comes to historical injustices and redress. That said, while original sin talk can be employed in public moral discourse and used as a diagnostic tool in policies of redress, we should not attempt to apply it to the legal domain. A strictly legal approach to issues of morality and culpability cannot resolve the social problems created by centuries of injustice. To solve the impasses of human history we need to go beyond legal rights discourse. Even as original sin language reminds us of the collective burden of guilt we carry as a human species, it is not designed to lead us into fatalism. Genesis 1 is fittingly located at the very beginning of the primeval history. It tells us that the goodness of God's creation enjoys logical priority over sin talk. Christian theology does not start with sin-talk, neither does it end with sin talk. Salvation and healing have the last word. Admittedly, we cannot change the past nor can we rectify the past in an unadulterated form, but we can undo many of the remnants of the past through spontaneous acts of self-sacrifice, embrace, reconciliation and restoration. In the end, land reform depends on attitudes, political will and social cooperation. In my view clear social diagnosis and sincere reconciliatory language carries much more promise than retributive expropriation without compensation talk or legalist liberal rights discourse.

\section{BIBLIOGRAPHY}

Asal, Victor, Udi Sommer and Paul G. Harwood. Original sin: A cross-national study of the legality of homosexual acts, Comparative Political Studies 46 (2013), no. 3: 320-351. doi/10.1177/0010414012453693.

Augustine. Contra Faustus Manicaeum [Reply to Faustus the Manichaean], in The writings against the Manicheans and the Donatists. A select library of the Nicene and Post-Nicene fathers of the Christian Church, edited by Phillip Schaff, volume 4. Grand Rapids Mich.: Eerdmans, 1956. 
Augustine. Dei Civitate Dei [The City of God], in A select library of the Nicene and Post-Nicene fathers of the Christian Church, edited by Phillip Schaff, volume 2. Grand Rapids Mich.: Eerdmans, 1956.

Augustine. De Peccatorum Meritis et Remissione, et de Baptismo Parvulorum [On the merits and remission of sins, and on the baptism of infants], in Writings against the Pelagians. A select library of the Nicene and Post-Nicene fathers of the Christian Church, edited by Phillip Schaff, volume 5. Grand Rapids Mich.: Eerdmans, 1956, 12-80.

Balkan, Elazar. Historical reconciliation: Redress, rights and politics, Journal of International Affairs 60 (2013), no. 1:1-15.

Barth, Karl. The doctrine of reconciliation, KD iv/1, translated by G.W. Bromiley. Edinburgh: T \& T Clark, 1956.

Bavinck, Herman. Gereformeerde dogmatiek, volume 3. Kampen: Kok, 1929.

Bonds, Anne and Joshua Innwood. Beyond white privilege: Geographies of white supremacy and settler colonialism, Progress in Human Geography 40 (2015), no. 6:715-733. https://doi.org/10.1177/0309132515613166.

Bonnhoeffer, Dietrich. Creation and fall. A theological exposition of Genesis 1-3. Minneapolis: Fortress Press, 2004.

Cohen, Jeremy. Original sin as the evil inclination. A polemicist's appreciation of human nature, Harvard Theological Review 73, no. 4 (1980):495-520.

Conradie, Ernst. Redeeming sin? Social diagnostics amid ecological destruction. Lanham: Lexington Books, 2017.

Conradie, Ernst. The project/prospects of Redeeming Sin?, paper read at a colloquium on "Redeeming Sin", San Diego, California, November 2019.

Cousins, Ben and Ian Scoones. Contested paradigms of viability in redistributive land reform: Perspectives from Southern Africa, The Journal of Peasant Studies 37 (2010), no. 1:31-66.

Duffy, Stephen J. Our hearts of darkness: Original sin revisited, Theological Studies 49 (1988):597-622.

Frye, Timothy. Original sin, good works and property rights in Russia, World Politics 58 (2006):479-504.

Gibney, Mark, Rhoda E. Howard Hassmann, Jean Marc-Coicaud and Niklaus Steiner. The Age of Apology: Facing up to the past. Pennsylvania: University of Pennsylvania Press, 2008.

Horton, Michael. The Christian faith. A systematic theology for pilgrims on the way. Grand Rapids Mich.: Zondervan, 2011.

Jenson, Robert. Systematic theology, volume 2. Oxford: Oxford University Press, 1999.

McFadyen, Alistair I. Bound to sin. Abuse, holocaust and the Christian doctrine of sin. Cambridge: Cambridge University Press, 2000.

McFarland, Ian A. The fall and sin, in The Oxford handbook of systematic theology, edited by Kathryn Tanner, John Webster and Iain Torrance. Oxford: Oxford University Press, 2007.

McGrath, Alister. Heresy. A history of defending the truth. New York: Harper, 2012. 
Mehl, Arnaud, and Julian Reynaud. The determinants of domestic original sin in emerging market economies. Working Paper Series no 560. Frankfurt: European Central Bank, 2005.

Niebuhr, Reinhold. The nature and destiny of man, volume 1. London: Nisbet, 1941.

Ricoeur, Paul. Original sin. A study in meaning, in The conflict of interpretations, edited by Don Ihde. London: Continuum, 265-284, 1989.

South African Institute for Race Relations, Submission to the Joint Constitutional Review Committee regarding its Review of Section 25 and other Sections where necessary to make it possible for the State to Expropriate Land in the Public Interest without Compensation. https://irr.org.za/reports/submissions-onproposed-legislation/irr-full-submission-to-joint-constitutional-review-committee14-june-2018.pdf. Accessed 11 September 2018.

Van der Elst, Herman. Die wegbeweeg vanaf gematigdheid na 'n radikale grondverdelingsbenadering as transformasie prioriteit in Suid-Afrika, Tydskrif vir Geesteswetenskappe 57 (2017), no. 4:955-970.

Van der Kooi, Cornelis and Van den Brink, Gijsbert. Christian dogmatics. An introduction. Grand Rapids Mich.: Eerdmans, 2017.

Volf, Miroslav. Exclusion and embrace. A theological exploration of identity, otherness and reconciliation. Nashville: Abingdon Press, 1996.

Vorster, Koos. The ethics of land restitution, Journal of Religious Ethics 34, no. 4:685707.

Vorster, Nico. Christian theology and racist ideology: A case study of Nazi theology and Apartheid theology, Journal for the Study of Religions and Ideologies 7 (2008), no. 19:144-161.

Vorster, Nico. Land and identity in South Africa: An immanent moral critique of dominant discourses in the debate on expropriation without compensation, HTS 75, no. 4 (2019): 1-9.

Vorster, Nico. Land, group identities and competing justice values in South Africa: Reformed perspectives on embracive justice and permeable identity formation, In Luce Verbi 53 (2019), no. 1:1-9.

Vumelana Advisory Fund. Submission to the Joint Constitutional Review Committee on the Review of Section 25 of the Constitution to make it possible for the State to expropriate Land in the Public Interest without Compensation. www.vumelana.org.za/wpcontent/uploads/2018/06/00_Vumelana_submission_14 _Jun_2018_vFINAL.pdf. Accessed 20 September 2018.

Wallis, Jim. Original sin: Racism, white privilege and the bridge to a new America. Grand Rapids, Mich.: Brazos Press, 2016. 
See Frye, Original sin, good works and property rights, 482, 485.

Mehl and Reynaud, The determinants of domestic original sin, 5, 7 .

Asal, Sommer and Harwood, Original sin: A cross national study, 320-351.

Gibney, Hassmann, Marc-Coicaud and Steiner, The Age of Apology.

See Wallis, Original sin: Racism, white privilege and the bridge to a new America.

www.youtube.com/watch?v=Sa zu3SxjaHc.

See Conradie, The project/prospects of Redeeming Sin?, 1.

8 A number of important publications on original sin emanated from the series of colloquia. See Conradie,

Redeeming sin? Social diagnostics amid ecological destruction, 61-107; Van der Kooi and Van den Brink,

Christian dogmatics, 318-324; Daniel Houck, Aquinas, original sin, and the challenge of evolution.

Cambridge: Cambridge University Press (2020) and Rachel Baard, Sexism and sin-talk: Feminist

conversations on the human condition. Westminster: John Knox Press (2019).

9 South African Institute for Race Relations, Submission to the Joint Constitutional Review Committee.

10 For instance, on 14 October 2018 Ramaphosa made similar comments about the "original sin" of land dispossession when he facilitated the handover of 4586 hectares of land to a community in Kwamkhwanasi, Kwazulu Natal. See Jeff Wicks, We will be returning land in a massive way: Ramaphosa, 14 October 2018, https://www.timeslive.co.za/news/south-africa/2018-10-14-we-will-be-returning-land-in-a-massive-wayramaphosa/.

11 Carin Smith, Ramaphosa: Growing black anger about lackadaisical whites in power. Financial Times 13 December 2018, https://www.fin24.com/Economy/ramaphosa-growing-black-anger-about-lackadaisicalwhites-with-power-20181213; Siyabonga Mkwanazi, Cyril defends Mmusi's white privilege remarks, Politics 9 May 2018, https://www.iol.co.za/news/politics/ramaphosaqanda-cyril-defends-mmusis-white-privilegeremarks-14853355; Marianne Merten, Parliament: historic land expropriation agreement reached amid South Africa's changing politics, Daily Maverick 28 February 2018, https://dailymaverick.co.za/section/south-africa. Thuli Madonsela, Waaroor ek en Zille tee drink. Maatskaplike onreg is die grootste uitdaging van ons generasie [Why myself and Zille drank tea together. Social injustice is the greatest challenge of our times], Rapport 2 June 2019, 7; Bonds and Innwood, Beyond white privilege, 716, 721. Bonds and Innwood, Beyond white privilege, 716.

14 Allen Choruma, How to defuse South Africa's ticking land time-bomb, New African 2017 (November), 3233 .

15 Vumelana Advisory Fund, 2018, Submission to the Joint Constitutional Review Committee, 8.

16 Ricoeur, Original sin. A study in meaning, 265-284.

17 Conradie distinguishes between four historical Christian approaches to the emergence of sin, namely the notion that good is original and corruption total (Augustine), good is original and corruption not total (Pelagian), good and evil are co-original and in constant conflict (Manichean) and good and evil were first "undifferentiated" (Irenaen). According to Conradie, these models have analogies in the public realm in the form of the Manichaean-Darwinian-capitalist, the Augustinian-Marxist, the Pelagian-liberal and the IrenaenWhiteheadian-Teilhardian trajectories. See Conradie, Redeeming sin? Social diagnostics amid ecological destruction, 61-106. The exact typology is open for debate, but the resemblances in Christian and social discourse on evil are striking and illustrate the possibility of a phenomenological approach to evil (see in this regard Van der Kooi and Van den Brink, Christian dogmatics, 295). Ibid, 267, 276.

19 Ibid, 266.

20 Ibid. 269.

Ibid, 270. See Augustine, Dei Civitate Dei, 12.7.

2 Ricoeur, Original sin, 274, 275.

23 See Augustine, De Peccatorum Meritis et Remissione, 1.13.

24 Ricoeur, Original sin, 273, 276.

25 Ibid, 273. See Augustine, Contra Faustum, 22.78.

26 Ricoeur, Original sin, 273.

27 Ibid, 280.

28 Barth, KD iv/1, 501.

29 Niebuhr, The nature and destiny of man, 278.

30 Duffy, Original sin revisited, 607. 
Barth, KD iv/l, 508.

McFarland, Fall and sin, 142.

Jenson, Systematic theology, 149.

Ibid.

Augustine, Dei Civitate Dei, 13.13, 14.15.

See Cohen, Original sin as the evil inclination, 495-520.

Bavinck, Gereformeerde dogmatiek, 97, 101.

See McGrath, Heresy, 170.

Ibid.

See McFadyen, Bound by sin, 169.

Horton, The Christian faith, 428.

Rom 6:16-17.

Horton, The Christian faith, 433.

See Eph 2:8-9; Rom 8:3.

Niebuhr, The nature and destiny of man, 276.

Jenson, Systematic theology, 103.

47 See McFadyen, Bound to sin, 9.

48 Matt 20:1-16.

49 Vorster, Land, group identities and competing justice values, 7.

50 McFarland, Fall and sin, 148-149.

51 See 2 Thess 2:11-12, Rom 1:24-28, Jer 50:6-8; Isa 6, Jonah 1.

52 McFarland, Fall and sin, 148.

53 Ibid, 142.

54 McFadyen, Bound to sin, 4.

55 Ibid, 6, 11.

56 Ibid, 6.

57 Duffy, Original sin revisited, 616.

58 Ibid, 12.

59 Jenson, Systematic theology, 150.

60 Conradie, The project/prospects of Redeeming Sin?, 9.

61 Ibid, 6.

62 Jenson, 15.

63 Bonnhoeffer, Creation and fall, 117.

64 Vorster, Land, group identities and competing justice values, 2.

65 Cousins and Scoones, Contested paradigms of viability, 32.

66 Vorster, Land, group identities and competing justice values, 2; Van der Elst, Die wegbeweeg vanaf gematigdheid na " $n$ radikale grondverdelingsbenadering, 959. Jenson, Systematic theology, 137.

68 See Vorster, The ethics of land restitution, 686.

69 See Vorster, Christian theology and racist ideology, 144-161.

70 As quoted in Niebuhr, The nature and destiny of man, 195.

71 See Ibid, 190.

72 Volf, Exclusion and embrace, 83.

73 Ibid, 82.

74 Conradie, The project/prospects of Redeeming Sin?", 8.

75 Balkan, Historical reconciliation: Redress, rights and politics, 4. 